DOI: $\underline{\text { http://doi.org/10.21698/simi.2018.fp39 }}$

\title{
A BASELINE ASSESSMENT OF WATER QUALITY FROM PRIVATE WELLS LOCATED IN CONSTANTA COUNTY AND RISK IMPLICATIONS FOR COMMUNITY HEALTH
}

\author{
Gina Vasile Scaeteanu, Roxana Maria Madjar
}

University of Agronomic Sciences and Veterinary Medicine, Faculty of Agriculture, 59 Marasti Blvd., 011464, Bucharest, rmadjar@yahoo.com, Romania

\begin{abstract}
The aim of the research was to evaluate the quality of drinking water from five private wells (W1-W5) located in Negresti-Cobadin, Constanta County, Romania. The evaluation consisted in determination of some specific parameters as $\mathrm{pH}$, electrical conductivity (EC), total hardness (TH), ammonium, nitrate and nitrite concentrations and oxidisability index. The results were compared with quality standards for drinking water imposed by Council Directive 98/83/EC and also with Romanian legislation. The $\mathrm{pH}$, EC, nitrite and ammonium levels for all water samples are within recommended ranges. The $\mathrm{TH}$ values are higher and range between 27.41 and $47.14 \mathrm{mg} \mathrm{CaO} / \mathrm{L}$. Concerning nitrate levels, it is noteworthy to mention that excepting W4 sampling point, all water samples exceeded (as average) maximum admitted level. Oxidisability parameter indicates for wells W1-W4 values were below $5 \mathrm{mg} \mathrm{O}_{2} / \mathrm{L}$, meanwhile in the case of $\mathrm{W} 5$ found value exceeded slightly limit value.
\end{abstract}

Keywords: conductivity, nitrate, nitrite, pollution, water.

\section{Introduction}

Protecting the quality of drinking water is a major challenge considering that the presence of undesirable pollutants may be unacceptable due to their health effects and decrease of water quality. Among the contaminants of water, nitrate and nitrite species occupy an important place and is a common problem in many parts of the world and it is generated by agriculture (fertilizers and manure), domestic activities, municipal wastewater and sludge, septic systems (Scaeteanu et al 2014). The main manifestation of high nitrate levels in drinking water or food is methemoglobinemy, which appears mainly to babies or to elder people (Santamaria 2006).

Given that drinking water quality is an actual and astringent problem and the presence of some chemical species above limits are harmful for human health, it was evaluated some specific parameters ( $\mathrm{pH}$, electrical conductivity (EC), total hardness (TH), nitrate, nitrite, ammonium, oxidisability) for well water samples collected from Negresti-Cobadin, Constanta County, Romania, during 2016-2017.

Measurement of various water quality parameters provides information to facilitate protection of the community health, to investigate and identify pollution sources. Monitoring long-term trends in source water quality leads to prepare for future challenges of regulations. 


\section{Materials and Methods}

Water samples were collected from five wells (labelled W1-W5) located in Negresti-Cobadin, Constanta County, Romania. The samples were collected from wells during three sampling campaigns: S1 (October 2016), S2 (January 2017) and S3 (April 2017). Selected wells represent sources of drinking water and are used also for domestic usage as cooking, washing, etc. It was analyzed 15 water samples in triplicate (5 wells $\times 3$ sampling moments) and the results are average of the determinations. All samples were collected in polyethylene bottles rinsed with sample water before collection and were carried to the laboratory where were stored at $4^{\circ} \mathrm{C}$ to avoid possible degradation of chemical species that are present in water. Chemical analyses were conducted within 48 hours of collection. A presentation of the analyses, methods and apparatus used for analytical determination of the subjected parameters are presented elsewhere (Scaeteanu \& Madjar 2017).

The experiment was designed as a bifactorial one and the studied factors are: A factor - the location and $\mathbf{B}$ factor - the sampling moment.

\section{Results and Discussion}

The obtained results (as average of determinations) are presented in Table 1.

Table 1. The average values of the quality parameters for well water

\begin{tabular}{c|cccccc}
\hline Well & $\mathrm{pH}$ & $\begin{array}{c}\mathrm{EC} \\
\mu \mathrm{S} / \mathrm{cm}\end{array}$ & $\begin{array}{c}\mathrm{TH} \\
(\mathrm{mg} \mathrm{CaO} / \mathrm{L})\end{array}$ & $\begin{array}{c}\mathrm{NO}_{3}^{-} \\
\mathrm{mg} / \mathrm{L}\end{array}$ & $\begin{array}{c}\mathrm{NO}_{2}^{-} \\
\mathrm{mg} / \mathrm{L}\end{array}$ & $\begin{array}{c}\text { Oxidisability } \\
\mathrm{mg} \mathrm{O} \mathrm{O}_{2} / \mathrm{L}\end{array}$ \\
\hline W1 & 7.12 & 1343 & 28.33 & 64.23 & 0.048 & 2.52 \\
W2 & 7.25 & 1505 & 32.10 & 145.31 & 0.082 & 2.37 \\
W3 & 7.21 & 1274 & 30.90 & 50.46 & 0.020 & 1.89 \\
W4 & 7.04 & 1124 & 27.41 & 19.55 & 0.019 & 2.16 \\
W5 & 7.18 & 2207 & 47.14 & 235.56 & 0.110 & 5.22 \\
Limits & $\mathbf{6 . 5 - 9 . 5}$ & $\mathbf{2 5 0 0}^{*}$ & $\mathbf{m i n . 5}$ & $\mathbf{5 0}^{*}$ & $\mathbf{0 . 5}^{*}$ & $\mathbf{5}^{*}$ \\
& & & $\mathbf{2 0 - 3 0 *}^{*}$ & & & \\
\hline
\end{tabular}

*According to Official Journal of the European Communities, Council Directive 98/83/EC (1998) and to Law no. 458/2002 (2011); **STAS 1342/1991

The influence of location (A factor) and sampling moment (B factor) on $\mathrm{pH}$ value from water samples collected from Negresti-Cobadin, Constanta County

The average of the determinations for $\mathrm{pH}$ parameter is between 7.04 and 7.25, these values being within limits imposed by legislation (6.5-9.5). There are no significant differences between W2, W3 and W5 sampling points and significant as against W1 and W4. The results of the analyses indicate a neutral to slightly alkaline reaction for analyzed water samples. The influence of the sampling moment on $\mathrm{pH}$ average values indicates significant differences with the highest value in S3 moment (7.64). Similar $\mathrm{pH}$ values for well water collected from Patarlagele and Paltinis villages, Buzau County (Senila et al 2017) and Maneciu-Ungureni, Prahova County (Scaeteanu \& Madjar 2017) were reported. According to literature, drinking water should be almost neutral with pH values between 6.8-8.5 (Cohl et al 2014). 
Table 2. The influence of location (A factor) and sampling moment (B factor) on $\mathrm{pH}$ value from water samples

\begin{tabular}{c|cccc}
\hline B & & & & S3 \\
A & S1 & S2 & Average A \\
\hline W1 & $\mathrm{a} 6.80 \mathrm{~b}$ & $\mathrm{a} 7.20 \mathrm{a}$ & $\mathrm{b} 7.37 \mathrm{a}$ & $\mathbf{b 7 . 1 2}$ \\
W2 & $\mathrm{a} 6.85 \mathrm{c}$ & $\mathrm{a} 7.15 \mathrm{~b}$ & $\mathrm{a} 7.75 \mathrm{a}$ & $\mathbf{a 7 . 2 5}$ \\
W3 & $\mathrm{b} 6.64 \mathrm{c}$ & $\mathrm{a} 7.27 \mathrm{~b}$ & $\mathrm{a} 7.72 \mathrm{a}$ & $\mathbf{a 7 . 2 1}$ \\
W4 & $\mathrm{b} 6.54 \mathrm{c}$ & $\mathrm{b} 6.95 \mathrm{~b}$ & $\mathrm{a} 7.63 \mathrm{a}$ & $\mathbf{b 7 . 0 4}$ \\
W5 & $\mathrm{b} 6.60 \mathrm{c}$ & $\mathrm{a} 7.22 \mathrm{~b}$ & $\mathrm{a} 7.74 \mathrm{a}$ & $\mathbf{a 7 . 1 8}$ \\
Average B & $\mathbf{6 . 6 9 c}$ & $\mathbf{7 . 1 6 b}$ & $\mathbf{7 . 6 4 a}$ &
\end{tabular}

Average A: LSD 5\%=0.10*; LSD $1 \%=0.15 ;$ LSD $0.1 \%=0.23$

Average B: LSD 5\%=0.08*; LSD $1 \%=0.11 ;$ LSD $0.1 \%=0.16$

${ }^{1} \mathrm{~B}$ constant A variable: LSD $5 \%=0.18^{*} ;$ LSD $1 \%=0.25 ;$ LSD $0.1 \%=0.35$

${ }^{2} \mathrm{~A}$ constant B variable: $\mathrm{LSD} 5 \%=0.19 *$; LSD $1 \%=0.26$; LSD $0.1 \%=0.36$

There were made interpretations by LSD 5\% indicated in the table by “*”

${ }^{1}$ Means with different letters in a column (in front of data) are significant different.

${ }^{2}$ Means with different letters in a row (in back of data) are significant different.

The influence of location (A factor) and sampling moment (B factor) on EC value from water samples collected from Negresti-Cobadin, Constanta County

The average values of EC $(\mu \mathrm{S} / \mathrm{cm})$ for analyzed water samples indicate significant differences for all sampling points, the highest average value being encountered for W5 (2207 $\mu \mathrm{S} / \mathrm{cm})$, but lower than maximum admitted limit (2500 $\mu \mathrm{S} / \mathrm{cm})$.

Table 3. The influence of location (A factor) and sampling moment (B factor) on EC $(\mu \mathrm{S} / \mathrm{cm})$ value from water samples

\begin{tabular}{c|cccc}
\hline B & & & & \\
A & S1 & S2 & S3 & Average A \\
\hline W1 & c1366a & c1375a & c1288b & c1343 \\
W2 & b1472b & b1545a & b1497b & b1505 \\
W3 & d1288a & d1295a & d1239b & d1274 \\
W4 & e1129a & e1109b & e1135a & e1124 \\
W5 & a1733b & a1748b & a3140a & a2207 \\
Average B & $\mathbf{1 3 9 8 c}$ & $\mathbf{1 4 1 4 b}$ & $\mathbf{1 6 6 0 a}$ &
\end{tabular}

Average A: LSD 5\%= 10.44* $\mu \mathrm{S} / \mathrm{cm}$; LSD $1 \%=15.19 \mu \mathrm{S} / \mathrm{cm} ;$ LSD $0.1 \%=22.83 \mu \mathrm{S} / \mathrm{cm}$

Average B: LSD 5\%= 9.73* $\mu \mathrm{S} / \mathrm{cm}$; LSD $1 \%=13.27 \mu \mathrm{S} / \mathrm{cm} ;$ LSD $0.1 \%=17.95 \mu \mathrm{S} / \mathrm{cm}$

${ }^{1} \mathrm{~B}$ constant A variable: $\mathrm{LSD} 5 \%=19 * \mu \mathrm{S} / \mathrm{cm}$; LSD $1 \%=27 \mu \mathrm{S} / \mathrm{cm} ; \mathrm{LSD} 0.1 \%=37 \mu \mathrm{S} / \mathrm{cm}$

${ }^{2}$ A constant B variable: LSD 5\%= 22* $\mu \mathrm{S} / \mathrm{cm} ;$ LSD $1 \%=30 \mu \mathrm{S} / \mathrm{cm} ;$ LSD $0.1 \%=40 \mu \mathrm{S} / \mathrm{cm}$

There were made interpretations by LSD 5\% indicated in the table by “*”

${ }^{1}$ Means with different letters in a column (in front of data) are significant different.

${ }^{2}$ Means with different letters in a row (in back of data) are significant different.

Significant differences are given by sampling moment, but with average values lower than $2000 \mu \mathrm{S} / \mathrm{cm}$, excepting S3 sampling moment for W5 sampling point $(3140 \mu \mathrm{S} / \mathrm{cm})$. Similar results were reported for well water collected from Buzău County (Senila et al 2017), meanwhile much lower values for EC were found for water samples collected Prahova County (Scaeteanu \& Madjar 2017). 


\section{INTERNATIONAL SYMPOSIUM "THE ENVIRONMENT AND THE INDUSTRY", SIMI 2018, PROCEEDINGS BOOK}

The influence of location (A factor) and sampling moment (B factor) on TH value from water samples collected from Negresti-Cobadin, Constanta County

The values for $\mathrm{TH}$ parameter is between 28.33 and $47.14 \mathrm{mg} \mathrm{CaO} / \mathrm{L}$, higher than the minimum value of $5 \mathrm{mg} \mathrm{CaO} / \mathrm{L}$ imposed by legislation (Law no. 458/2002 2011), with no significant differences between W1, W2, W3 and W4 but with significant differences as against W5. The influence of the sampling moment on $\mathrm{TH}$ average values indicates significant differences, the highest value being encountered in S3 for W5 (67.08 $\mathrm{mg} \mathrm{CaO} / \mathrm{L}), 2.23$ times higher than recommended value of $30 \mathrm{mg}$ $\mathrm{CaO} / \mathrm{L}$. This result is concordance with slightly alkaline reaction of water samples. Drinking water with high total hardness may produce nephrolithiasis, influence iron absorption or produce laxative effects. Also, the degree of water hardness is correlated with aesthetic acceptability by consumers (WHO 2011).

Table 4. The influence of location (A factor) and sampling moment (B factor) on $\mathrm{TH}$ (mg CaO/L) value from water samples

\begin{tabular}{c|cccc}
\hline B & & & & \\
A & S1 & S2 & S3 & Average A \\
\hline W1 & a37.63a & a28.00b & c19.37c & b28.33 \\
W2 & a43.45a & a27.32b & b25.53b & b32.10 \\
W3 & a40.76a & b23.96b & b28.00b & b30.90 \\
W4 & a38.08a & b19.26b & b24.91b & b27.41 \\
W5 & a40.32b & a34.03c & a67.08a & a47.14 \\
Average B & $\mathbf{4 0 . 0 5 a}$ & 28.51c & $\mathbf{3 2 . 9 8 b}$ &
\end{tabular}

Average A: LSD 5\%=5.14* mgCaO/L; LSD $1 \%=7.49 \quad \mathrm{mgCaO} / \mathrm{L} ; \quad$ LSD $0.1 \%=11.25$ $\mathrm{mgCaO} / \mathrm{L}$

Average B: LSD 5\%= 3.64* mgCaO/L; LSD $1 \%=4.97 \quad \mathrm{mgCaO} / \mathrm{L} ; \quad$ LSD $0.1 \%=6.73$ $\mathrm{mgCaO} / \mathrm{L}$

${ }^{1} \mathrm{~B}$ constant A variable: LSD 5\%=7.68* $\mathrm{mgCaO} / \mathrm{L} ; \mathrm{LSD} 1 \%=10.73 \mathrm{mgCaO} / \mathrm{L} ; \quad \mathrm{LSD}$ $0.1 \%=15.10 \mathrm{mgCaO} / \mathrm{L}$

${ }^{2} \mathrm{~A}$ constant B variable: LSD 5\%=8.15* $\mathrm{mgCaO} / \mathrm{L} ; \mathrm{LSD} 1 \%=11.12 \mathrm{mgCaO} / \mathrm{L} ; \quad \mathrm{LSD}$ $0.1 \%=15.05 \mathrm{mgCaO} / \mathrm{L}$

There were made interpretations by LSD 5\% indicated in the table by “*”

${ }^{1}$ Means with different letters in a column (in front of data) are significant different.

${ }^{2}$ Means with different letters in a row (in back of data) are significant different.

The influence of location (A factor) and sampling moment (B factor) on nitrate levels from water samples collected from Negresti -Cobadin, Constanta County

The average content for nitrate in water samples indicate significant differences with concentrations higher than limit value of $50 \mathrm{mg} / \mathrm{L}$ for four sampling points (W1, W2, W3, W4). The highest average value is $235.56 \mathrm{mg} / \mathrm{L}$ for $\mathrm{W} 5$, this being 4.71 times higher than maximum admitted level. The influence of sampling moment on average values indicates significant differences with concentrations that exceed the limit value. The highest concentration is $141.30 \mathrm{mg} / \mathrm{L}$ for S3, for this sampling moment being found also the value $400.17 \mathrm{mg} / \mathrm{L}$ for W5, 8 times higher than maximum admitted level. The lowest concentrations are recorded for $\mathrm{W} 4$, with an average of $19.55 \mathrm{mg} / \mathrm{L}$ and the sample collected at S3 present the lowest nitrate level of $16.90 \mathrm{mg} / \mathrm{L}$.

A study developed in Romania during 2009 (Tudor \& Staicu 2009) revealed that $58 \%$ from reported cases of infant methemoglobinemy appeared when consumed 


\section{INTERNATIONAL SYMPOSIUM "THE ENVIRONMENT AND THE INDUSTRY", SIMI 2018, PROCEEDINGS BOOK}

well water was 101-500 mg/L nitrate-contaminated. Also, 20\% of cases were reported when nitrate levels were between 0-50 mg/L.

Table 5. The influence of location (A factor) and sampling moment (B factor) on nitrate levels $(\mathrm{mg} / \mathrm{L})$ value from water samples

\begin{tabular}{|c|c|c|c|c|}
\hline$\frac{\mathbf{B}}{\mathbf{A}}$ & S1 & $\mathrm{S} 2$ & S3 & Average A \\
\hline W1 & c61.10b & c76.35a & c55.25c & c64.23 \\
\hline W2 & b110.83c & b139.78b & b185.34a & b145.31 \\
\hline W3 & d51.05a & d51.49a & d48.86b & d50.46 \\
\hline W4 & e21.32a & e20.44a & e16.90b & e19.55 \\
\hline W5 & a158.23b & a148.29c & $\mathrm{a} 400.17 \mathrm{a}$ & a235.56 \\
\hline Average B & 80.51c & 87.27b & $141.30 \mathrm{a}$ & \\
\hline \multicolumn{5}{|c|}{$\begin{array}{l}\text { Average A: LSD } 5 \%=2.35^{*} \mathrm{mg} / \mathrm{L} ; \mathrm{LSD} 1 \%=3.43 \mathrm{mg} / \mathrm{L} ; \mathrm{LSD} 0.1 \%=5.15 \mathrm{mg} / \mathrm{L} . \\
\text { Average B: LSD 5\%= } 0.65^{*} \mathrm{mg} / \mathrm{L} ; \mathrm{LSD} 1 \%=0.88 \mathrm{mg} / \mathrm{L} ; \mathrm{LSD} 0.1 \%=1.20 \mathrm{mg} / \mathrm{L} . \\
{ }^{1} \text { B constant A variable: } \mathrm{LSD} 5 \%=2.07 * \mathrm{mg} / \mathrm{L} ; \mathrm{LSD} 1 \%=2.97 \mathrm{mg} / \mathrm{L} ; \mathrm{LSD} 0.1 \%=4.38 \mathrm{mg} / \mathrm{L} . \\
{ }^{2} \text { A constant B variable: } \mathrm{LSD} 5 \%=1.45^{*} \mathrm{mg} / \mathrm{L} ; \mathrm{LSD} 1 \%=1.98 \mathrm{mg} / \mathrm{L} ; \mathrm{LSD} 0.1 \%=2.68 \mathrm{mg} / \mathrm{L} \text {. }\end{array}$} \\
\hline
\end{tabular}

The influence of location (A factor) and sampling moment (B factor) on nitrite levels from water samples collected from Negresti-Cobadin, Constanta County The influence of location on nitrite concentrations indicates no significant differences between W3 and W4 and significant as against the other locations. The found values are between $0.019-0.110$ and are below limit value of $0.5 \mathrm{mg} / \mathrm{L}$. The influence of sampling moment an average values present significant differences with values that are below limit value, the highest concentration $(0.169 \mathrm{mg} / \mathrm{L})$ being found in the case of W5 at S3 sampling moment.

Having in view the cumulative hazardous effect of the simultaneous presence nitrate and nitrite in drinking water according to Council Directive 98/83/EC, there must be ensured the relation: [nitrate] $/ 50+[$ nitrite] $/ 3 \leq 1$, where the square brackets represent the concentrations in $\mathrm{mg} / \mathrm{L}$ for both species. The results in our study conducted to the following values: 1.30 for W1, 2.93 for W2, 1.01 for W3, 0.39 for W4, 4.74 for W5. As it may be observed, for W1, W2, W3 and W5 the calculated parameter exceeded the limit value, the highest value being found in the case of the well with highest nitrate and nitrite levels.

There are many studies that deal with nitrate and nitrite levels found in well water collected from different areas in Romania. Extreme values of nitrate, higher than $300 \mathrm{mg} / \mathrm{L}$ were reported for Matca (Galati County), Sahateni (Buzau County) and Clinceni (Ilfov County) (Pele et al 2010). Concerning nitrite, values above $0.5 \mathrm{mg} / \mathrm{L}$ were detected in well water from Matca (Pele et al 2010). Also, in well water from Ozun village (Covasna) nitrate levels exceeded the limit value even 3 times, meanwhile nitrite concentrations were within safe limit (Raduly \& Farkas 2017). 


\section{INTERNATIONAL SYMPOSIUM "THE ENVIRONMENT AND THE INDUSTRY", SIMI 2018, PROCEEDINGS BOOK}

Table 6. The influence of location (A factor) and sampling moment (B factor) on nitrite levels $(\mathrm{mg} / \mathrm{L})$ value from water samples

\begin{tabular}{c|cccc}
\hline B & S1 & S2 & S3 & Average A \\
\hline W1 & b0.074a & $\mathrm{b} 0.050 \mathrm{~b}$ & $\mathrm{~d} 0.020 \mathrm{c}$ & $\mathbf{c 0 . 0 4 8}$ \\
W2 & $\mathrm{c} 0.038 \mathrm{c}$ & $\mathrm{a} 0.074 \mathrm{~b}$ & $\mathrm{~b} 0.134 \mathrm{a}$ & $\mathbf{b 0 . 0 8 2}$ \\
W3 & $\mathrm{e} 0.010 \mathrm{~b}$ & $\mathrm{c} 0.023 \mathrm{a}$ & $\mathrm{c} 0.028 \mathrm{a}$ & $\mathbf{d 0 . 0 2 0}$ \\
W4 & $\mathrm{d} 0.029 \mathrm{a}$ & $\mathrm{c} 0.018 \mathrm{~b}$ & $\mathrm{e} 0.011 \mathrm{c}$ & $\mathbf{d 0 . 0 1 9}$ \\
W5 & $\mathrm{a} 0.109 \mathrm{~b}$ & $\mathrm{~b} 0.053 \mathrm{c}$ & $\mathrm{a} 0.169 \mathrm{a}$ & $\mathbf{a 0 . 1 1 0}$ \\
Average B & $\mathbf{0 . 0 5 2 b}$ & $\mathbf{0 . 0 4 4 c}$ & $\mathbf{0 . 0 7 2 a}$ &
\end{tabular}

Average A: LSD 5\%= 0.005* mg/L; LSD $1 \%=0.007 \mathrm{mg} / \mathrm{L}$; LSD $0.1 \%=0.011 \mathrm{mg} / \mathrm{L}$.

Average B: LSD 5\%=0.002* mg/L; LSD $1 \%=0.003 \mathrm{mg} / \mathrm{L}$; LSD $0.1 \%=0.004 \mathrm{mg} / \mathrm{L}$.

${ }^{1} \mathrm{~B}$ constant A variable: LSD 5\%=0.005* mg/L; LSD 1\%=0.008 mg/L; LSD $0.1 \%=0.012$ $\mathrm{mg} / \mathrm{L}$.

${ }^{2} \mathrm{~A}$ constant B variable: LSD $5 \%=0.005 * \mathrm{mg} / \mathrm{L} ; \mathrm{LSD} 1 \%=0.0071 \mathrm{mg} / \mathrm{L} ; \quad \mathrm{LSD}$ $0.1 \%=0.0103 \mathrm{mg} / \mathrm{L}$.

There were made interpretations by LSD 5\% indicated in the table by “*”

${ }^{1}$ Means with different letters in a column (in front of data) are significant different.

${ }^{2}$ Means with different letters in a row (in back of data) are significant different.

There are many studies that deal with nitrate and nitrite levels found in well water collected from different areas in Romania. Extreme values of nitrate, higher than $300 \mathrm{mg} / \mathrm{L}$ were reported for Matca (Galati County), Sahateni (Buzau County) and Clinceni (Ilfov County) (Pele et al 2010). Concerning nitrite, values above $0.5 \mathrm{mg} / \mathrm{L}$ were detected in well water from Matca (Pele et al 2010). Also, in well water from Ozun village (Covasna) nitrate levels exceeded the limit value even 3 times, meanwhile nitrite concentrations were within safe limit (Raduly \& Farkas 2017).

The influence of location (A factor) and sampling moment (B factor) on oxidisability ( $\mathrm{mg} \mathrm{O}_{2} / \mathrm{L}$ ) from water samples collected from Negresti -Cobadin, Constanta County Oxidisability parameter indicates water pollution and is expressed as amount of oxygen that oxidize organic species. Clean water usually has oxidisability between 2-4 $\mathrm{mg} \mathrm{O}_{2} / \mathrm{L}$ (Cohl et al 2014).

Table 7. The influence of location (A factor) and sampling moment (B factor) on oxidisability parameter $(\mathrm{mg} / \mathrm{L})$ from water samples

There were made interpretations by LSD 5\% indicated in the table by “*”

\begin{tabular}{|c|c|c|c|c|}
\hline A & S1 & S2 & S3 & Average A \\
\hline W1 & $\mathrm{b} 2.16 \mathrm{~b}$ & $\mathrm{~b} 2.80 \mathrm{a}$ & b2.61a & b2.52 \\
\hline W2 & b2.08c & c2.32b & b2.70a & b2.37 \\
\hline W3 & c1.92a & $\mathrm{d} 2.00 \mathrm{a}$ & c1.76b & d1.89 \\
\hline W4 & $\mathrm{c} 1.84 \mathrm{~b}$ & $\mathrm{~b} 2.80 \mathrm{a}$ & $\mathrm{c} 1.84 \mathrm{~b}$ & c2.16 \\
\hline W5 & $\mathrm{a} 4.40 \mathrm{~b}$ & a3.20c & a8.07a & a5.22 \\
\hline Average B & $2.48 \mathrm{c}$ & $2.62 b$ & $3.40 \mathrm{a}$ & \\
\hline \multicolumn{5}{|c|}{ 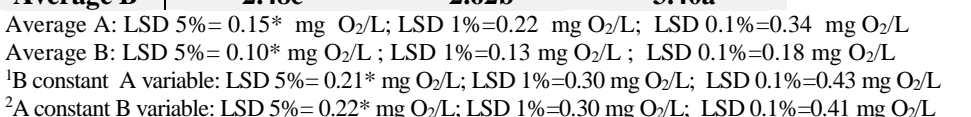 } \\
\hline
\end{tabular}




\section{INTERNATIONAL SYMPOSIUM "THE ENVIRONMENT AND THE INDUSTRY", SIMI 2018, PROCEEDINGS BOOK}

The average values for oxidisability parameter indicate no significant differences for W1 and W2 and significant as against W3, W4 and W5 with values between 1.89$5.22 \mathrm{mg} \mathrm{O}_{2} / \mathrm{L}$. For one well was found a slightly higher value $\left(5.22 \mathrm{mg} \mathrm{O}_{2} / \mathrm{L}\right)$ than limit $\left(5 \mathrm{mg} \mathrm{O}_{2} / \mathrm{L}\right)$. The influence of the sampling moment on average values indicates significant differences with values lower than imposed limit. The highest value is found for W5 at S3 $\left(8.07 \mathrm{mg} \mathrm{O}_{2} / \mathrm{L}\right), 1.61$ times higher than limit value. The lowest values were encountered for W3 (1.89 $\mathrm{mg} \mathrm{O} / \mathrm{L}$, as average), the sample collected from W3 at S3 presenting the lowest oxidisability value $\left(1.76 \mathrm{mg} \mathrm{O}_{2} / \mathrm{L}\right)$.

\section{Conclusions}

The main objective of the research was to monitor water quality parameters such as $\mathrm{pH}$, electrical conductivity (EC), total hardness ( $\mathrm{TH}$ ), oxidisability, nitrate, nitrite and ammonium concentrations in wells located in Negresti-Cobadin, Constanta County during 3 sampling campaigns (during 2016-2017) from 5 wells. The results of the analyses led to the conclusions presented below:

The $\mathrm{pH}$ and EC for all water samples are within reccomended ranges, 6.5-9.5 pH units and $2500 \square \mathrm{S} / \mathrm{cm}$, respectively.

The $\mathrm{TH}$ values are higher and range between 27.41 and $47.14 \mathrm{mgCaO} / \mathrm{L}$ (as average), these values being often encountered for well water.

Violations of the parametric value for nitrate $(50 \mathrm{mg} / \mathrm{L})$ imposed by European and Romanian legislation were detected for a large number of water samples $\mathbf{7 3 . 3 3 \%}$ from total). Excepting W4 sampling point, all water samples exceeded (as average) maximum admitted level. For W5 the found value was 4.71 times higher than limit value.

Nitrite levels were below maximum admitted level, the highest average concentration (for W5) being 4.54 times lower than limit value $(0.5 \mathrm{mg} / \mathrm{L})$.

Ammonium levels for all sampling points and sampling moments were below detection limit of the method.

Oxidisability parameter for wells W1-W4 presented values below $5 \mathrm{mg} \mathrm{O} / \mathrm{L}$, meanwhile in the case of W5 found value exceeded slightly limit value (5.22 mg $\mathrm{O}_{2} / \mathrm{L}$, as average).

As a general conclusion, the values of some subjected parameters ( $\mathrm{pH}$, conductivity) are similar with those already reported for other areas (Maneciu-Ungureni, Prahova County, Patarlagele and Paltinis villages, Buzau County). Nitrate contents of W1W4 analyzed water samples are similar with those found for water collected from Clinceni, meanwhile for W5 nitrate concentrations are comparable with those found for some wells located in Sahateni. The identified values of nitrite are similar with those reported for Branesti but higher than those from Sahateni. Oxidisability parameter determined in this study presents values higher than those reported for Maneciu-Ungureni, Prahova County (1.33-2.61 $\left.\mathrm{mgO}_{2} / \mathrm{L}\right)$.

\section{References}

Cohl, M, Lazar, L \& Balasanian, I 2014, 'Study on the quality of water supply sources for Iași city, Romania', Environmental Engineering and Management Journal, vol. 13, no.9, pp 2301-2310.

Law 458/2002 (r1) 2011, regarding drinking water quality, republished and amended by Order no 22/2017. In Romanian. 


\section{INTERNATIONAL SYMPOSIUM "THE ENVIRONMENT AND THE INDUSTRY", SIMI 2018, PROCEEDINGS BOOK}

Official Journal of the European Communities, Council Directive 98/83/EC 1998, on the quality of water intended for human consumption.

Pele, M, Vasile, G \& Artimon, M 2010, 'Studies regarding nitrogen pollutants in well waters from Romania', Scientific Papers UASMV Bucharest, Series A, Agronomy, vol. LIII, pp 145-151.

Raduly, OC \& Farkas, A 2017, 'Nitrate, nitrite and microbial denitrification in drinking water from Ozun village (Covasna County, Romania) and the association between changes during water storage', Studia Universitatis BabesBolyai Biologia, vol. LXII, no. 1, pp 17-28.

Santamaria, P 2006, 'Nitrate in vegetables-toxicity, content, intake and EC regulation', Journal of the Science of Food and Agriculture, vol. 86, pp 10-17.

Senila, M, Micu, D, Hoaghia, A, Levei, E, Cadar, O, Kucsicsa, G \& Balteanu, D 2017, 'Multivariate statistical analysis of water chemistry in wells from SubCarpathians of Curvature, Romania', AES Bioflux, vol. 9, no.1, pp 64-71.

Tudor, A \& Staicu, C 2009, 'Methemoglobinemia acuta infantila generata de apa de fantana în anul 2009', National report.

Scaeteanu Vasile, G \& Madjar, RM 2017, 'Evaluation of well water quality collected from Maneciu-Ungureni, Prahova County, Romania', SGEM 2017 Vienna GREEN Conference Proceedings, vol. 17, no.33, pp 151-162.

Scaeteanu Vasile, G Madjar, RM, Penescu, A, Dinca, EP \&Terzea, IA 2014, 'Nitrate monitoring in private wells from Prahova District', Scientific Papers Series A, Agronomy, vol. LVII, pp 68-73.

WHO 2011, Hardness in drinking-water. Background document for development of WHO Guidelines for Drinking-water quality. 